\title{
A Literature Review of Homelessness and Aging: Suggestions for a Policy and Practice-Relevant Research Agenda*
}

\author{
Amanda Grenier, ${ }^{1,2}$ Rachel Barken, 2,3 Tamara Sussman, ${ }^{4}$ David Rothwell, ${ }^{4}$ \\ Valérie Bourgeois-Guérin, ${ }^{5}$ and Jean-Pierre Lavoie ${ }^{4}$
}

\begin{abstract}
RÉSUMÉ
Le sans-abrisme chez les personnes âgées est une préoccupation croissante à travers le Canada et devrait augmenter avec le changement démographique (Crane \& Warnes, 2010; Culhane, Métraux, Byrne, Stino, et Bainbridge, 2013). Pourtant, les connaissances actuelles, les politiques et les pratiques concernant le sans-abrisme ont tendance largement de se concentrer sur des populations plus jeunes. De même, la recherche et les politiques sur le vieillissement en général négligent le sans-abrisme. Les réponses au problème de sans-abrisme chez les personnes âgées doivent répondre aux besoins complexes liés à la santé, la sécurité du revenu et le logement. Basé sur un examen exhaustif de la littérature, cet article présente les domaines de recherche afin d'éclairer les politiques, les stratégies et les services pour les divers groupes des aînés sans-abri. Nous clarifions les intersections du vieillissement et du sans-abrisme; examinons les statistiques pertinentes, y compris la prévalence estimée; discutons des voies et des variations de l'expérience; et determinons les lacunes dans les connaissances. Nous concluons par un appel à un programme de recherche inclusive qui aidera à créér des politiques et des pratiques visant à réduire et finalement à éliminer le sans-abrisme chez les personnes âgées au Canada.
\end{abstract}

\begin{abstract}
Homelessness among older people is a growing concern across Canada and is expected to rise with demographic change (Crane \& Warnes, 2010; Culhane, Metraux, Byrne, Stino, \& Bainbridge, 2013). Yet current knowledge, policies, and practices on homelessness largely focus on younger populations. Likewise, research and policies on aging typically overlook homelessness. Responses to homelessness among older people must address complex needs related to health, income security, and housing. Based on a comprehensive literature review, this article outlines the existing and needed research with regards to homelessness among older people. We clarify the intersections of aging and homelessness; review the relevant statistics, including estimated prevalence; discuss pathways and variations in experience; and identify gaps in knowledge. We conclude with a call for an inclusive research agenda that will help build policies and practices to reduce and ultimately to eliminate homelessness among older people in Canada.
\end{abstract}

1 Department of Health, Aging, and Society, McMaster University

2 Gilbrea Centre for Studies on Aging, McMaster University

3 Department of Sociology, McMaster University

4 School of Social Work, McGill University

5 Psychologie, Université du Québec à Montréal, UQAM

* The research in this article is funded by an Insight grant from the Social Sciences and Humanities Research Council of Canada (SSHRC; project number 435-2012-1197). The authors wish to thank Rachel Weldrick, Laura McGhie, Sebastien Mott, Laura Henderson, and Malorie Moore for their work on the project.

Manuscript received: / manuscrit reçu : 07/01/14

Manuscript accepted: / manuscrit accepté : 13/04/15

Mots clés : vieillissement, personnes (plus) âgées, risque, exclusion sociale, pauvreté, logement

Keywords: aging, older people, risk, social exclusion, poverty, housing

La correspondance et les demenades de tire-à-part doivent être adressées à: / Correspondence and requests for offprints should be sent to:

Amanda Grenier, Ph.D.

Department of Health, Aging, and Society

McMaster University 
Kenneth Taylor Hall, Room 228

1280 Main Street West

Hamilton, ON, L8S 4M4

(grenier@mcmaster.ca )

A substantial literature focuses on homelessness and social programming (Lee, Tyler, \& Wright, 2010; Shlay \& Rossi, 1992; Toro, 2007; Trypuc \& Robinson, 2009), yet major gaps exist. At present, knowledge and practices on homelessness tend to focus on young adults and young families, with less attention to older people (Beynon, 2009; Burns, Grenier, Lavoie, Rothwell, \& Sussman, 2012; Cohen, 1999; Crane \& Warnes, 2001; Gonyea, Mills-Dick, \& Bachman, 2010; McDonald, Dergal, \& Cleghorn, 2004). However, with population aging (see Edmonston \& Fong, 2011), the number of older homeless people is expected to rise (Crane \& Warnes, 2010; Culhane, Metraux, Byrne, Stino, \& Bainbridge, 2013). A strong evidence base is required to address the unique challenges of older homelessness. ${ }^{1}$

Based on a comprehensive literature review, this article sets the stage for a research agenda that will inform national and provincial strategies; policies in housing, health, and social care; and community services for Canada's older homeless population. After a brief comment on homelessness in Canada, we clarify the intersections of aging and homelessness and sketch out the existing knowledge that can be used to counter homelessness. Drawing on international and Canadian research, we review terminology, definitions, and distinctions in the literature; available statistics and the estimated prevalence of homelessness in Canada; pathways into homelessness in later life; and examples of heterogeneous experiences that exist among older homeless people.

\section{Homelessness in Canada}

Canada has a vast social geography, with regional or place differences affecting homelessness in unique ways. Federal, provincial, territorial, regional, municipal, and Aboriginal governments have all invested in homelessness reduction strategies (Gaetz, Donaldson, Richter, \& Gulliver, 2013). At the federal level, the government funds and supports targeted communities through the Homelessness Partnering Strategy (HPS), launched in 2007 and renewed in 2013 (Employment and Social Development Canada, 2014). ${ }^{2}$ To date, responses to homelessness have focused primarily on crisis response delivered through shelters and emergency health care. Recently, however, communities across Canada have embraced a housing-first model that is intended to immediately provide housing, followed by other forms of support. ${ }^{3}$ Results from At Home/ Chez Soi - the major nationwide demonstration project that tested the housing first approach in five
Canadian cities - suggests that this model can effectively reduce homelessness, and that it is less costly than emergency responses (Goering et al., 2014). ${ }^{4}$

Despite the number of initiatives taking place across the country, there is little attention to the unique needs of older homeless people, or to determining whether suggested approaches are effective for older people (e.g., Gaetz et al., 2013; Goering et al., 2014). An exception is Quebec's national strategy on homelessness, which in addition to committing $\$ 52$ million to homelessness (CBC News, 2014) considers the specific challenges, vulnerabilities, and needs of homeless people over age 50 (Gouvernement du Québec, 2014). Recognizing older people as a population at risk is a first step, but concerted policies regarding resource allocation and the development of services designed to meet older people's needs, including housing programs for older people, are still missing across Canada.

\section{Methodology: A Literature Review on Homelessness among Older People}

This article reports the results of a comprehensive literature review of research published between 1978 and 2014. Locating literature on homelessness among older people required multiple stages of testing search terms and a manual review of printed titles. ${ }^{5,6}$ The successful search strategy, carried out in Web of Science databases, employed the terms older adult, senior, elder, elderly, old age, and late life to identify articles related to older people $(1,106,339$ results), combined with the terms homeless, homelessness, and unhoused (771 results). A manual review of the 771 articles deemed 163 articles to be relevant. A final pool of 140 articles was selected for review once duplicates and book reviews were removed.

Summarizing the literature to arrive at a general understanding of homelessness among older people was challenging due to variations in methodologies, samples, and research foci. Studies concentrated on homeless women or men, particular trajectories (e.g., substance use, violence, mental health, etc.), and tended to be city or region specific. Further, the heterogeneity of the homeless population made it difficult to separate the impacts of age in combination with "race", class, gender, health status, geography, service availability, and so forth (Aubry, Farrell, Hwang, \& Calhoun, 2013; Rothwell \& Mott, 2013). Results were also constrained by a paucity of literature on the intersecting locations of homelessness in late life, as well as by reported 
challenges of access and maintained contact over time (Greenwood, Schaefer-McDaniel, Winkel, \& Tsemberis, 2005; O'Connell et al., 2004). This review is a best attempt to outline the state of knowledge in the field and to identify gaps, in order to stimulate an agenda that is inclusive of the needs of diverse groups of older people who are homeless (or at risk of becoming so).

\section{Defining Aging and Homelessness}

Definitions and categories of homelessness vary among sources and between programs. The Canadian Homelessness Research Network (2012) comprehensively describes homelessness as "the situation of an individual or family without stable, permanent, appropriate housing, or the immediate prospect, means and ability of acquiring it" (p. 1). Their definition specifies four groups of homeless people: the unsheltered, the emergency sheltered, the provisionally sheltered, and those at risk of homelessness. Other sources use homeless in a narrower, more literal sense, referring to those who live in temporary shelters or on the streets. People who tend to avoid shelters and outreach services are often referred to as "rough sleepers" (Crane \& Warnes, 2000; Johnsen, Cloke, \& May, 2005; O'Connell et al., 2004). ${ }^{7}$

Distinctions are made between transitional or temporary, episodic or cyclical, and chronic homelessness (Aubry et al., 2013; Culhane \& Metraux, 2008; Echenberg \& Jensen, 2008; Kuhn \& Culhane, 1998; Rothwell \& Mott, 2013). Some researchers define the chronic category as three months of homelessness (Trypuc \& Robinson, 2009), whereas others categorize people who are repeatedly homeless for more than one year as chronically homeless (McDonald et al., 2004). Against this backdrop, there are two notable trends where older people are concerned. First, people who are chronically homeless often use shelters as a means of housing rather than an emergency service. Second, chronically homeless people tend to be older, persistently unemployed, and are more likely to be disabled or use substances (Mott, 2012).

Attempts to define homelessness among older people exist, but are more limited. There is general acceptance that homelessness among older people is increasing (Crane \& Warnes, 2010; Culhane et al., 2013), but differences in life trajectories and health status present challenges to defining the parameters of an older homeless population (McDonald, Dergal, \& Cleghorn, 2007). While 65 - the dominant age of retirement - is the most widely accepted marker of old age, it is deficient where homelessness is concerned. Older people who are homeless tend to exhibit mental and physical health characteristics that are more consistent with nonhomeless people who are approximately 10 years older than they are (Cohen, 1999; Gonyea et al., 2010; Hibbs et al., 1994; Hwang et al., 1998; Morrison, 2009; Ploeg, Hayward, Woodward, \& Johnston, 2008). A study of older homeless people in Toronto found that those over 50 subjectively considered themselves "old" (McDonald et al., 2004), reflecting the general trend of considering homeless people over 50 as "older" (Cohen, 1999; Garibaldi, Conde-Martel, \& O'Toole, 2005; Gonyea et al., 2010; McDonald et al., 2007; Ploeg et al., 2008; Shinn et al., 2007). People who live on the streets also have higher rates of early mortality than the general population (Cohen, 1999; Hibbs et al., 1994; Hwang et al., 1998; Morrison, 2009), with the average age of death for a homeless person in Canada cited as 39 years (Trypuc \& Robinson, 2009). Given these findings, we suggest that 50 is an appropriate age threshold for research and programming for older people.

\section{Statistics and Estimated Prevalence of Homelessness among Older People}

Prevalence statistics normally provide the foundation to develop a research and policy agenda, but the incidence of homelessness - specifically homelessness among older people - is difficult to attain (Link et al., 1994; Mott, Moore, \& Rothwell, 2012). Homelessness is a global issue, and an estimated 100 million people are homeless worldwide (United Nations Organization, 2005). Yet Canada does not gather comprehensive data on homelessness (Trypuc \& Robinson, 2009). The data collected by Statistics Canada is based on the number of people living in shelters (Statistics Canada, 2012) and this makes it difficult to estimate the number of people who are unsheltered, provisionally sheltered, or who are at risk of homelessness. Different understandings of the living circumstances that constitute homelessness, the realities of transitions between places (i.e., lack of fixed address), and varied counting methods further complicate this issue. Some studies use a point prevalence count to estimate the number of homeless people at a specific time. To arrive at their results, researchers conduct a survey of shelter users and count the number of individuals in "homeless hotspots" on one night. In other studies, researchers use a period prevalence count to estimate the homeless population over a given duration (Hulchanski, 2000). The use of administrative data, such as the recorded number of people using a shelter over a given length of time, is an example of the period prevalence method. ${ }^{8}$

Despite limitations, prevalence estimates suggest that Canada's homeless population ranges from 150,000 to 300,000 , with particular groups, such as Aboriginal populations, greatly over-represented (Goering et al., 2014; Laird, 2007; Patrick, 2014). ${ }^{9}$ Approximately 20,170 individuals $(0.05 \%$ to $0.06 \%$ of the population) lived in shelters between 2001 and 2011 (Statistics Canada, 2012), 
and in 2008 there were 1,128 shelters in Canada (Echenberg \& Jensen, 2008). Data suggests that Toronto has the largest number of homeless people in the country, but cities in Alberta also have significant rates of homelessness (Gaetz et al., 2013). Information collected by point prevalence methods indicates that there were approximately 5,086 homeless people on a single night in Toronto in 2008 (representing $0.19 \%$ of the city population); 1,602 on one night in Vancouver in 2012 (representing $0.27 \%$ of the city population); and 3,190 on one night in Calgary in 2012 (representing 0.29\% of the city population) (Gaetz et al., 2013). Although comparable data for Montreal are not currently available, Montreal is expected to conduct its first point in time count in 2015.

The age structure of the homeless population is even more difficult to assess, but data suggest that approximately 6 per cent of the visible homeless population in Canada are over age 65 (Stuart \& Arboleda-Flórez, 2000) and 9 per cent are over 55 (Social Planning and Research Council of BC, 2005). Data suggest that Toronto has a large proportion of older homeless people, with the 2013 point in time count reporting that 29 per cent of the homeless population in Toronto is age 51 and older (City of Toronto, 2013). In terms of shelter use, people older than 55 are considered to represent 14 per cent to 28 per cent of shelter users (Stergiopoulos \& Herrmann, 2003). Although older people are a minority in the homeless population - perhaps due to their higher rates of early mortality - they are known to spend more time in shelters than their younger homeless counterparts (Serge \& Gnaedinger, 2003). With few viable housing alternatives for older people and over-crowding in acute hospitals, there is pressure on shelters to accept older and unwell patients who can no longer care for themselves, and to fill the gap in convalescent care (Serge \& Gnaedinger, 2003). Little is known, however, about patterns of shelter use among certain sub-groups of the older homeless population such as older Aboriginal people or older immigrants.

\section{Older People's Pathways into Homelessness}

Identifying trajectories into homelessness provides insight into the needs and challenges of older people who are homeless. Research indicates that a gradual decline and/or trigger event(s) (Gonyea et al., 2010; Shinn et al., 2007), as well as various individual and structural factors, contribute to homelessness among older people. The following discussion attempts to untangle the complex interconnections between structural conditions, cumulative circumstances, risk factors, and trigger events. Our goal is to give readers a better sense of the diverse conditions that operate and are associated with homelessness among older people.
Macro-level forces that disadvantage particular groups of older people are considered to increase the risk of homelessness. Although Canada funds supports and services for older people, ${ }^{10}$ structural issues associated with homelessness in later life include (a) inadequate affordable housing; (b) fewer available jobs; (c) poverty; and (d) policies that limit the access of particular populations to health, disability, and pension benefits (Gaetz et al., 2013; Lee et al., 2010; Tully \& Jacobson, 1994). Since the 1990s, the rising cost of housing has also resulted in more Canadians living below the low-income cut-off in urban and rural areas (Skaburskis, 2004). Although the impacts of the recent global recession and economic crisis have yet to be adequately researched, literature suggests that poverty among older people is a growing concern. Asset poverty research, for example, shows that 28 per cent of people age 66 and older do not have sufficient financial assets to survive at the low-income threshold for three months (Rothwell \& Haveman, 2013).

In this context, individuals may experience a gradual decline into homelessness through precarious employment, diminishing finances leading to poverty, poor mental and physical health, decreasing social connections (Morris, Judd, \& Kavanagh, 2005; Shinn et al., 2007), psychiatric conditions (Barak \& Cohen, 2003), or alcoholism (Crane, 1999; Dietz, 2009). Lower levels of education (Rank \& Williams, 2010), precarious work history, and incarceration (Kushel, Evans, Perry, Robertson, \& Moss, 2003; Metraux \& Culhane, 2006) are also associated with a greater risk of homelessness. Those who experience higher levels of victimization and poverty when younger are also more likely to be homeless later in life (Browne \& Bassuk, 1997; Koegel, Melamid, \& Burnam, 1995; North, Smith, \& Spitznagel, 1994; Stein, Leslie, \& Nyamathi, 2002; Toro, 2007), as are those who experience traumatic life changes, especially if the individual has limited social and family networks (Morris et al., 2005). Aboriginal people and lesbian, gay, bisexual, transgendered, and queer people (LGBTQ) are also over-represented in the homeless population (Addis, Davies, Greene, MacBride-Stewart, \& Shepherd, 2009; Patrick, 2014).

At the individual level, people who experience vulnerabilities may lack the personal, economic, or social resources to cope with emergency situations. In turn, events such as housing loss; death of a spouse, relative, or close friend who may have provided care; domestic violence; and/or family breakdown may trigger homelessness (Crane \& Warnes, 2005; Gonyea et al., 2010). Such situations may be increasingly complex for older people. For example, a Toronto study found that 70 per cent of people over age 50 became homeless between the ages of 41 and 60 as a result of family breakdown, eviction, and/or a loss of employment (McDonald et al., 2004). 
Older people typically experience one of two types of homelessness: they are either homeless throughout their lives and continue this pattern as they age (i.e., chronic homelessness), ${ }^{11}$ or they become homeless for the first time in later life (i.e., late-life homelessness). The literature suggests that the second pathway is increasingly common. Research conducted with older homeless people in the United States, England, and Australia found that two thirds had not experienced homelessness earlier in life, while the other third had been homeless before (Crane et al., 2005). ${ }^{12}$ In addition to representing a new sub-population of homeless people, older people typically experience longer periods of homelessness than younger people because they are less likely to reintegrate into the workforce (Caton et al., 2005). Concerns about the rising numbers of people who are homeless for the first time in late life in Canada (McDonald et al., 2007), and internationally (Caton et al., 2005; Crane et al., 2005), underscore the importance of identifying and responding to populations who are already homeless, as well as those who are at risk.

\section{Gaps in Knowledge: Sub-populations in the Older Homeless Population}

Here we summarize, and extrapolate beyond our literature review, to draw attention to under-researched trends with regards to gender, over-represented subpopulations, geography, health, substance use, and the unique needs of older people who are homeless. Some of the findings presented here are constrained by a limited (or in some cases non-existent) body of research. Greater attention to the impacts of age in combination with life course inequalities produced by "race", class, gender, ability, health status, and geography is urgently needed to set an inclusive agenda, and to design and implement programs that reduce and ultimately eliminate homelessness among diverse groups of older people in Canada.

\section{Gender}

Research suggests that men outnumber women about four to one among all homeless people (Cohen, 1999), but the gender gap is thought to be narrower among older people (McDonald et al., 2007). The gender difference in estimated prevalence reflects that men are more likely to use shelter services, and are thus more visible in the homeless population (Rich \& Clark, 2005). By contrast, the prevalence of older homeless women is likely under-reported, particularly among those leaving abusive situations (Kosor \& KendalWilson, 2002). With homeless women less visible, it is difficult to provide precise information on gender differences. However, research does point to divergent paths of men and women. On the one hand, men are more likely to be homeless or precariously housed throughout their lives (Hecht \& Coyle, 2001), with their homelessness often connected to loss of employment (McDonald et al., 2004), mental health problems, or addiction (Peressini, 2007). Older homeless women, on the other hand, often experience poverty as a result of family circumstances, the structure of the pension system (Rahder, 2006), as well as trigger events such as family breakdown (McDonald et al., 2004), eviction (Hecht \& Coyle, 2001), and abuse (Kosor \& KendalWilson, 2002). ${ }^{13}$ Other studies suggest that the number of women over age 55 forced to leave their homes because of physical and sexual violence is increasing (Grossman \& Lundy, 2003), and that when homeless, women experience much higher risks of abuse and victimization than men (Dietz \& Wright, 2005; Wenzel, Leake, \& Gelberg, 2001). Older women's housing needs are also complicated by a national shortage of shelters and social housing units for abused women (Rahder, 2006).

\section{Over-represented Populations}

Research conducted on earlier parts of the life course confirms that a disproportionate number of Aboriginal people; lesbian, gay, bi-sexual, transgendered, and queer (LGBTQ) people; and immigrants are homeless or at risk of homelessness in Canada (Fiedler, Schuurman \& Hyndman, 2006; Gaetz, 2006; Goering et al., 2014; Patrick, 2014). ${ }^{14}$ Although older people are rarely considered in this literature on over-represented subpopulations, we expect that members of these groups will face unique challenges as they age (Brotman, Ferrer, Sussman, Ryan, \& Richard, 2014), and may experience difficulties exiting homelessness in later life. ${ }^{15}$ Aboriginal people are noted to be over-represented by a factor of 10 in the Canadian homeless population (Hwang, 2001) - a trend that is associated with historical and current practices of colonialism, systemic discrimination and exclusion, and lack of affordable housing (Patrick, 2014). The one available study on older Aboriginal people who are homeless (an unpublished master's thesis; see Lange, 2010) highlights the unique challenges experienced by older Aboriginal people, including risks of homelessness when they move to cities for medical care. In such cases, older Aboriginal people tend to fall through the cracks of existing service structures because it is unclear whether governments or band organizations are responsible for their care (Lange, 2010). Similarly, although research on earlier periods of the life course finds that trajectories to homelessness are related to family breakdown among LGBTQ youth (Abramovich, 2013; Corliss, Goodenow, Nichols, \& Austin, 2011), we were unable to find literature on homelessness among older LGBTQ people. ${ }^{16}$ 
Contrasting with the dearth of research on older Aboriginal or LGBTQ people, a very small literature does exist on the intersections of age, homelessness, and immigration. The over-representation of immigrants in Canada's homeless population is attributed to their increased likelihood of poverty and housing insecurity, as well as their lower pension contributions (Springer, Webber, \& Lum, 2011). These findings have been extended to consider older people, with a Toronto study finding that 55 per cent of recently homeless older people were born outside of Canada, compared with 29 per cent of individuals who were chronically homeless (McDonald et al., 2007).

The lack of available research on the aging of overrepresented sub-populations reflects the widespread invisibility of marginalized groups and a failure to acknowledge inequalities that can result in homelessness. To better understand and address the needs of over-represented groups, responses to homelessness must account for the relationship between systemic factors such as discrimination, racism, and colonization; structural barriers and problems of access; and experiences of marginalization across the life course and in later life.

\section{Geographic Location}

The Canadian literature on homelessness among older people primarily notes geographic trends and urbanrural differences (e.g., McDonald et al., 2004). The majority of homeless people live in large cities (Statistics Canada, 2001) where services such as shelters are located, ${ }^{17}$ with shelter use reportedly higher in Quebec, Alberta, Ontario, British Columbia, and Manitoba than in other provinces and territories (Statistics Canada, 2001). At the same time, context and place-based issues are considered to impact experiences of homelessness among older people (Abbott \& Sapsford, 2005). While homelessness is typically considered an urban problem, those living outside urban or resource-based areas may draw on different strategies to meet their needs, or face additional challenges accessing services and support (North et al., 1994). With homelessness experienced differently among communities and across the country, geographic and place-based issues that may surface for diverse groups of older people (e.g., those new to homelessness in late life) require further investigation.

\section{Health Issues}

Health problems experienced across the life course are both a risk factor for, and an outcome of, homelessness. People with mental health or addiction problems are more likely to become homeless (Bhui, Shanahan, \& Harding, 2006). At the same time, people who lack stable housing face threats to their mental and physical health (Bhui et al., 2006; Power \& Hunter, 2001; Schanzer, Dominguez, Shrout, \& Caton, 2007), and older homeless people are considered to face greater physical and mental health disadvantages than younger groups (Dennis, McCallion, \& Ferretti, 2012; Gonyea et al., 2010; Kellogg \& Horn, 2012; Lipmann, 2009; Martins, 2008; Ploeg et al., 2008; Quine, Kendig, Russell, \& Touchard, 2004). Garibaldi et al. (2005) found that those over age 50 were 3.6 times more likely than younger homeless people to suffer from a chronic medical problem, while Kim, Ford, Howard, and Bradford (2010) noted that the likelihood of having mental health problems doubles for homeless people over the age of 42 .

Specific health issues have also been documented for older people who are homeless. McDonald et al. (2004) found that the most frequently reported ailments among older homeless people in Toronto were vision, arthritis, dental problems, and back problems, while Kellogg \& Horn (2012) found that hypertension, cardiac disease, lung disease, diabetes, and arthritis are prevalent among older homeless people in the United States. There are also gender differences in health issues, with women reporting greater difficulties with arthritis and bladder control, and men more likely to have back and skin problems (McDonald et al., 2004). Older homeless men particularly those who lose their jobs between ages 60 and 65 - are also at higher risk of suicide (Greater Vancouver Shelter Strategy, 2013). In some circumstances, health conditions are already present when one becomes homeless; in other cases, they manifest or worsen during periods of homelessness (Horn, 2008; Hwang et al., 1998).

Homelessness is also considered to have long-term effects on health and aging (Brown, Kiely, Bharel, \& Mitchell, 2012; Waldbrook, 2013). Those who are homeless are more likely than are older people in the general population to suffer from geriatric syndromes such as functional impairment, frailty, depression, visual impairment, and urinary incontinence (Brown et al., 2012). Where perceived health is concerned, formerly homeless older women, for example, express that the physical state of homelessness, lifelong socioeconomic disadvantage, trauma and stress, substance use, and neglect of health needs all contribute to poorer health in later life (Waldbrook, 2013).

\section{Substance Use}

Drug and alcohol use is often associated with homelessness (Blazer \& Wu, 2009; Dietz, 2009; Khandor \& Mason, 2008; Kuhn \& Culhane, 1998), but the literature on substance use among older people is inconclusive. Some research finds that substance use patterns differ between age cohorts and decrease with age (Blazer \& $\mathrm{Wu}, 2009$; Cohen, 1999). Other studies note that where 
younger and older homeless people are equally likely to report alcohol abuse (Dennis et al., 2012; Dietz, 2009; Hecht \& Coyle, 2001), older people are less likely to report drug use (Hecht \& Coyle, 2001). Conversely, some studies suggest that drug use among older people has been increasing and is expected to continue on an upward trajectory (Beynon, 2009; Proehl, 2007). In the United States, Garibaldi et al. (2005) find that those over age 50 are 2.4 times more likely to be dependent on heroin than those under 50 . Higher rates of drug use than previous generations are attributed to a cohort effect: people tend to maintain drug habits throughout their lives, and greater co-morbidity as a result of prolonged drug or alcohol use is expected (Beynon, 2009). Despite debates, it is clear that the paucity of relevant information and services on substance use among older homeless people leaves an already vulnerable population at greater risk (Blazer \& Wu, 2009; Proehl, 2007).

\section{Unique Needs of Older Homeless People}

Older and younger homeless people have shared needs that include housing, income, food, and health care. However, research finds that older people who are homeless also have unique needs with regards to safety and access to health and social services. ${ }^{18}$ Older homeless people are more likely than their younger counterparts to have mental and physical health concerns, and may require access to specialized medical care beyond what is available in shelters (Power \& Hunter, 2001). Living without a home can be especially challenging in later life, making older people's housing needs particularly urgent (Abbott \& Sapsford, 2005). Interviews with health care providers illustrate that mental health conditions can create challenges where continued engagement with older homeless people is concerned, and that memory problems for example, may cause some older people to forget appointments (Cohen, Onserud, \& Monaco, 1992; Horn, 2008; Proehl, 2007). Older homeless people's reports of discriminatory treatment and stigmatization in health care settings also demonstrate the need for medical staff to become more sensitive in their responses (Lipmann, 2009; Martins, 2008; Quine et al., 2004).

Difficulties navigating government services can also be a barrier to accessing supports and services. Many older homeless people do not receive the full amount of government assistance for which they qualify (Ploeg et al., 2008), and language has been identified as a significant barrier to accessing housing and support services among older people who are homeless (McDonald et al., 2007). There are also concerns regarding the appropriateness of services available for older homeless people. One Canadian project identified a gap in services for homeless people aged 50 to 65 , with clients reporting frustration because neither the services offered, nor the programs created for the general homeless population, suited their needs (McDonald, Donahue, Janes, \& Cleghorn, 2006).

Finally, older people who are homeless have unique needs regarding safety. They encounter violence on the streets and in shelters (Cohen et al., 1992; Lee \& Schreck, 2005; North et al., 1994) and are thought to face higher threats to safety than their younger counterparts because poorer health may mean they are seen as easy targets (Dietz \& Wright, 2005). Risks of victimization are especially high for older women and transgendered people, but older homeless men are also at high risk of physical abuse (Cohen, 1999; Dietz \& Wright, 2005; Gonyea et al., 2010; Grossman \& Lundy, 2003; Lee \& Schreck, 2005; North et al., 1994; Tully \& Jacobson, 1994).

\section{Building a Research Agenda to Inform Policy and Practice}

A strong knowledge base is necessary to address the needs of diverse groups of older people, develop provincial and national strategies to end homelessness, and design community services for this group. At present, the evidence base is limited by significant gaps. Table 1 outlines our suggested research agenda.

First, better estimates of the prevalence of older homelessness in Canada, and an identification of profiles of risk, are needed. Understanding how people become homeless for the first time, and which sub-populations are more likely to become or remain homeless in later life is especially urgent. We suggest that researchers make better use of data gathered through the Homeless Individuals and Families Information System (HIFIS) - an administrative tool for collecting detailed information on shelter users - to identify user profiles, patterns of shelter use, and people at extreme risk of long-term homelessness. Understanding homelessness can be enhanced if organizations link administrative data within and between cities and geographic areas. ${ }^{19}$ Carrying out this research on people over age 50 (instead of the standard age, 65), on those who are 40 to 49 and approaching old age (see Walsh, Hewson, Dooley, \& Pauls, 2013), and accounting for over-represented subpopulations can provide much-needed projection trends. Research suggests that many Canadians are financially vulnerable or asset poor (Brandolini, Magri, \& Smeeding, 2010; Rothwell \& Haveman, 2013), and that inadequate or limited access to pensions may contribute to poverty in later life, particularly for disadvantaged groups such as immigrants (McDonald et al., 2007) and women (Wakabayashi \& Donato, 2006). ${ }^{20}$ Over-represented sub-populations such as Aboriginal people and persons from the LGBTQ community also experience systemic discrimination and exclusion across the life course that 
Table 1: Research agenda for improved responses to homelessness among older people

\begin{tabular}{|c|c|}
\hline Research Priorities & Research Questions \\
\hline 4. Assess current and planned resource allocation & $\begin{array}{l}\text { - Which services best meet older people's needs? } \\
\text { - How do patterns of service use differ among older homeless } \\
\text { people in diverse socio-demographic groups and } \\
\text { over-represented populations? } \\
\text { - Which services are most cost-effective? What timing works? } \\
\text { - How can services be efficiently targeted and delivered? }\end{array}$ \\
\hline
\end{tabular}

likely place them at high risk of continued poverty and/or homelessness in later life (see Addis et al., 2009; Patrick, 2014).

Second, building appropriate strategies for diverse groups of older people who are homeless - or at risk of becoming homeless - requires a better understanding of intersecting needs for affordable housing and care in mid- to later life. Research assessing the supply of market-based and social housing in mid- to late life, both with and without available care, is needed. We suggest a two-pronged approach that focuses on re-housing people over age 50 who are homeless, and ensuring support for those who are precariously housed as they near "old age" and are vulnerable to situations that lead to homelessness (e.g., poverty, job loss, family conflict). Here Canada may look to international studies that consider how complex structural factors, including economic conditions and available housing, shape risks of homelessness in late life (see Byrne, Munley, Fargo, Montgomery, \& Culhane [2012] and Culhane et al. [2013] in the United States; and Crane \& Warnes [2001] in the United Kingdom). When researchers develop guidelines for housing strategies, they must be mindful of the following four areas: (a) rehousing people with limited financial resources as they transition from shelters or hospitals; (b) ensuring access to safe and affordable community housing, with links to health and social care supports; (c) ensuring an income base, and housing for at risk groups, including groups that are currently over-represented among homeless populations (e.g., Aboriginal people, older immigrants, LGBTQ people); and (d) ensuring access to appropriate services and long-term care when necessary. While implementing such changes relies heavily on political will, the recent literature underlines the importance of long-term, affordable, and secure housing for older people who are homeless or at risk of becoming so.

Third, and closely related, the research, policy, and practice agenda must draw closer attention to identifying intersecting inequalities experienced by overrepresented sub-populations. Given histories and current practices of colonialism, homophobia, racism, and sexism, older Aboriginal people, LGBTQ people, immigrants, and men/women may face particular challenges with regards to aging and homelessness. Therefore, research addressing multiple intersecting categories, including gender, class, "race", ethnicity, health status, and age, in specific geographic contexts, 
is necessary (see Brotman et al., 2014; Klodawsky, 2009). There are serious gaps in knowledge regarding the impact of sexual orientation on older people's risks of homelessness, and on the experiences of Aboriginal people who are aging in precarious situations. For members of these over-represented subpopulations, the structural and systemic challenges associated with income security, access to health care, and safe affordable housing can only be expected to continue - if not worsen - as they age. In this regard, a life course perspective that is attuned to the impacts of intersecting and cumulative inequalities could provide a basis for policy development as well as services and support.

Finally, addressing the needs of older homeless people will require greater knowledge on existing service structures and the challenges of implementing current strategies such as housing first. The literature clearly outlines that older people who are homeless have complex, intersecting needs for health and social care, income support, and housing. Access to services, however, is limited by rigid institutional boundaries, few options for affordable housing and care, ${ }^{21}$ and agebased thresholds for programs that exclude those aged 50 to 64 . We suggest that researchers and decisionmakers assess current and planned resource allocation, and the ways in which these resources could be revised to permit seamless movement across policy and service structures, in order to develop more-comprehensive support.

\section{Conclusion}

Homelessness among diverse groups of older people is a significant form of social marginalization that should be a pressing concern for decision-makers, gerontologists, and housing advocates alike. With homelessness among older people expected to rise and more people experiencing homelessness for the first time in later life or remaining in situations of homelessness as they age - a lack of research knowledge leaves policy-makers and practitioners with few directives from which to address the needs of older homeless people. Our review was intended to set the stage for an inclusive Canadian research, policy, and practice agenda that targets homelessness among older people. We have reviewed the state of knowledge on aging and homelessness; discussed the available statistics and the estimated prevalence of homelessness in Canada; articulated pathways into homelessness in later life; and drawn attention to within group variations and over-represented sub-populations in Canada. We have identified several gaps, including (a) accurate estimates of the older homeless population (including the diversity that exists within this population); (b) the availability of affordable housing; (c) the effects of intersecting inequalities on homelessness in later life; and (d) appropriate resources and supports. On the basis of these shortcomings, we advocate for the development of an agenda that will address gaps in knowledge through focused research, and stimulate a targeted response to homelessness that integrates the needs of diverse groups of older people in Canada.

\section{Notes}

1 The literature uses the terms older people, older adults, and older homelessness to refer to older people who are homeless. We use older people rather than the more clinical older adults to refer to our population group. We also draw on the term older homelessness that has been instrumental (most notably in the United Kingdom) in moving research into an agenda of action.

2 The 2013 renewal included a commitment by the federal government to invest $\$ 600$ million in the HPS between 2014 and 2019 (Employment and Social Development Canada, 2014).

3 The HPS supports housing first, but targeted communities have the flexibility to implement the model in ways that they feel are appropriate and in conjunction with other approaches (Employment and Social Development Canada, 2014).

4 When At Home/Chez Soi was completed in 2013, the original test cities, excluding Montreal, chose to continue implementing the housing-first approach. Quebec's decision to discontinue At Home/Chez Soi in Montreal, and opt out of the housing-first model, has been associated with political conflicts over federal involvement in housing, which is traditionally provincial jurisdiction.

5 A direct search strategy that combined all search terms (and/or/not etc.) yielded only four sources. A broad search combining the terms older adult, senior, elder, elderly, old age, and late life with homeless, homelessness, unhoused, displaced, precariously housed, houseless, marginally housed, and on the street yielded 3,696 results, with most being irrelevant (e.g., focused on older groups of youth, housing in general, or ethnographic approaches). A separate search of the terms related to aging and on the street, for example, yielded 76 results, with only four relevant to the research question. A decision was made to focus specifically on the group of older people considered homeless (homeless, homelessness, and unhoused).

6 Many citations appeared in search results because they included keyword tags such as homelessness or older adulthood. While some of these works could inform an agenda on older homelessness, they did not focus explicitly on homelessness among older people and were excluded from our review.

7 Although people who are provisionally accommodated or at risk fall under the umbrella of homelessness, this review primarily pertains to those considered "unsheltered" or who use emergency shelters.

8 The point prevalence method does not distinguish between people who are "unhoused" on one particular night, people 
who are episodically homeless, and people who are chronically homeless. The point prevalence method has been criticized for homogenizing among diverse groups of homeless people (Hulchanski, 2000) and for missing large proportions of the population - particularly those who leave highly visible spaces at night (Berry, 2007). Period prevalence is thought to give a better estimate of homelessness over time, although it may be unable to provide accurate estimates of hidden homeless populations, such as those who avoid shelters and other services (Berry, 2007; Hulchanski, 2000).

9 The lower number is a conservative estimate given by government sources, and the higher number is proposed by advocates and non-governmental sources in order to account for the rapid growth in municipal homelessness and persons who may not use homeless services (Laird, 2007).

10 A report comparing 21 OECD countries suggests that Canada's social policy expenditures are relatively equally distributed among people under and over age 65 (Lynch, 2001).

11 Chronic homelessness can include persons who move in and out of homelessness throughout life, not only those who remain homeless on an everyday basis.

12 As another example, a New York City study of 79 homeless people over age 55 finds that half of the participants lead what they considered "conventional lives" prior to becoming homeless. The other half was more likely to have experienced homelessness throughout their lives (Shinn et al., 2007).

13 For example, Kosor and Kendal-Wilson (2002) found that spousal abuse, family violence, and disputes with family and friends are major pathways to homelessness among older women.

14 Also see Rosario, Schrimshaw, and Hunter (2012) for risk factors of homelessness among lesbian, gay, and bisexual youth.

15 See Patrick (2014) for a literature review on Aboriginal homelessness in Canada.

16 See Addis et al. (2009) for a literature review on social care and housing needs of lesbian, gay, bisexual, and transgender older people.

17 Homeless people living in rural areas may be missed in both point prevalence counts, which often occur in cities, and in and period prevalence counts, which often rely on shelter data (Hulchanski, 2000). More-comprehensive counting methods are likely required to account for homeless people living in rural areas.

18 Older people also have unique needs for housing - an issue that requires a separate review (see Crane \& Warnes, 2007; McGhie, Grenier, \& Barken, 2013; Serge \& Gnaedinger, 2003).

19 Supplementing these data with an assessment of older people who use food banks and women's shelters (particularly related to abuse) can provide additional information on less visible groups such as women and recent immigrants.

20 Exploring connections between savings, pension allocation, employment histories, as well as use of food banks, community cafeterias, and shelters can contribute to more nuanced assessments of risks for homelessness.
21 There is inadequate space in long-term care, and home care policies require a domicile (although provincial differences exist between what is considered to comprise a "home").

\section{References}

Abbott, P., \& Sapsford, R. (2005). Living on the margins: Older people, place and social exclusion. Policy Studies, 26(1), 29-46.

Abramovich, A. (2013). No fixed address: Young, queer, and restless. In S. Gaetz, B. O'Grady, K. Buccieri, J. Karabanow, \& A. Marsolais (Eds.), Youth homelessness in Canada: Implications for policy and practice (pp. 387-403). Toronto, ON: Canadian Homelessness - Research Network, The Homeless Hub.

Addis, S., Davies, M., Greene, G., MacBride-Stewart, S., \& Shepherd, M. (2009). The health, social care and housing needs of lesbian, gay, bisexual and transgender older people: A review of the literature. Health $\mathcal{E}$ Social Care in the Community, 17(6), 647-658.

Aubry, T., Farrell, S., Hwang, S. W., \& Calhoun, M. (2013). Identifying the patterns of emergency shelter stays of single individuals in Canadian cities of different sizes. Housing Studies, 28(6), 910-927.

Barak, Y., \& Cohen, A. (2003). Characterizing the elderly homeless: A 10-year study in Israel. Archives of Gerontology and Geriatrics, 37(2), 147-155.

Berry, B. (2007). A repeated observation approach for estimating the street homeless population. Evaluation Review, 31, 166-199.

Beynon, C. M. (2009). Drug use and ageing: Older people do take drugs! Age and Ageing, 38(1), 8-10.

Bhui, K., Shanahan, L., \& Harding, G. (2006). Homelessness and mental illness: A literature review and a qualitative study of perceptions of the adequacy of care. International Journal of Social Psychiatry, 52(2), 152-165.

Blazer, D. G., \& Wu, L. T. (2009). The epidemiology of at-risk and binge drinking among middle-aged and elderly community adults: National survey on drug use and health. The American Journal of Psychiatry, 166(10), 1162-1169.

Brandolini, A., Magri, S., \& Smeeding, T. M. (2010). Assetbased measurement of poverty. Journal of Policy Analysis and Management, 29(2), 267-284.

Brotman, S., Ferrer, I., Sussman, T., Ryan, B., \& Richard, B. (2014). Access and equity in the design and delivery of health and social care to LGBTQ seniors: A Canadian perspective. In N. Orel, \& C. Fruhauf (Eds.), The lives of LGBTQ older adults: Understanding challenges and resilience (pp. 111-140). Washington, DC: American Psychological Association.

Brown, R. T., Kiely, D. K., Bharel, M., \& Mitchell, S. L. (2012). Geriatric syndromes in older homeless adults. Journal of General Internal Medicine, 27(1), 16-22.

Browne, A., \& Bassuk, S. S. (1997). Intimate violence in the lives of homeless and poor housed women: Prevalence 
and patterns in an ethnically diverse sample. American Journal of Orthopsychiatry, 67(2), 261-278.

Burns, V., Grenier, A., Lavoie, J. P., Rothwell, D., \& Sussman, T. (2012). Les personnes âgées itinérantes - invisibles et exclues. Une analyse de trois stratégies pour contrer l'itinérance. Frontières, 25(1), 31-56.

Byrne, T., Munley, E. A., Fargo, J. D., Montgomery, A. E., \& Culhane, D. P. (2012). New perspectives on communitylevel determinants of homelessness. Journal of Urban Affairs, 35(5) 607-625.

Canadian Homelessness Research Network. (2012). Canadian definition of homelessness. Retrieved from www.homelesshub.ca/CHRNhomelessdefinition

Caton, C. L. M., Dominguez, B., Schanzer, B., Hasin, D. S., Shrout, P. E., Felix, A., et al. (2005). Risk factors for longterm homelessness: Findings from a longitudinal study of first-time homeless single adults. American Journal of Public Health, 95(10), 1753-1759.

CBC News. (2014, February 27). Quebec unveils policy on homelessness. Retrieved from http://www.cbc.ca/ news / canada / montreal/ quebec-unveils-policy-onhomelessness-1.2554663

City of Toronto (2013). Street Needs Assessment. Toronto, ON. Retrieved from City of Toronto website: http:// www.toronto.ca /legdocs / mmis / 2013/cd/bgrd / backgroundfile-61365.pdf

Cohen, C. I. (1999). Aging and homelessness. The Gerontologist, 39(1), 5-14.

Cohen, C. I., Onserud, H., \& Monaco, C. (1992). Project rescue: Serving the homeless and marginally housed elderly. The Gerontologist, 32(4), 466-471.

Corliss, H. L., Goodenow, C. S., Nichols, L., \& Austin, S. B. (2011). High burden of homelessness among sexualminority adolescents: Findings from a representative Massachusetts high school sample. American Journal of Public Health, 101(9), 1683.

Crane, M. (1999). Understanding older homeless people: Their circumstances, problems and needs. Buckingham, England: Open University Press.

Crane, M., Byrne, K., Fu, R., Lipmann, B., Mirabelli, F., Rosa-Bartelink, A., et al. (2005). The causes of homelessness in later life: Findings from a 3-nation study. The Journals of Gerontology, 60B(3), S152-S159.

Crane, M., \& Warnes, A. (2000). Evictions and prolonged homelessness. Housing Studies, 15(5), 757-773.

Crane, M., \& Warnes, A. (2001). Older people and homelessness: Prevalence and causes. Topics in Geriatric Rehabilitation, 16(4), 1-14.

Crane, M., \& Warnes, A. (2005). Responding to the needs of older homeless people. Innovation: The European Journal of Social Science Research, 18(2), 137-152.
Crane, M., \& Warnes, A. (2007). The outcomes of rehousing older homeless people: A longitudinal study. Ageing and Society, 27(6), 891-918.

Crane, M., \& Warnes, A. M. (2010). Homelessness among older people and service responses. Reviews in Clinical Gerontology, 20(4), 354-363.

Culhane, D. P., \& Metraux, S. (2008). Rearranging the deck chairs or reallocating the lifeboats? Homelessness assistance and its alternatives. Journal of the American Planning Association, 74(1), 111-121.

Culhane, D. P., Metraux, S., Byrne, T., Stino, M., \& Bainbridge, J. (2013). The age structure of contemporary homelessness: Evidence and implications for public policy. Analyses of Social Issues and Public Policy, 13(1), 228-244.

Dennis, C. B., McCallion, P., \& Ferretti, L. A. (2012). Understanding implementation of best practices for working with the older homeless through the lens of self-determination theory. Journal of Gerontological Social Work, 55(4), 352-366.

Dietz, T., \& Wright, J. D. (2005). Victimization of the elderly homeless. Care Management Journals, 6(1), 15-21.

Dietz, T.L. (2009). Drug and alcohol use among homeless older adults: Predictors of reported current and lifetime substance misuse problems in a national sample. Journal of Applied Gerontology, 28(2), 235-255.

Echenberg, H., \& Jensen, H. (2008). Defining and enumerating homelessness in Canada. PRB-08-30-E. Ottawa, ON: Library of Parliament, Social Affairs Division. Retrieved from http:/ / www.parl.gc.ca/content/lop/ researchpublications/prb0830-e.htm

Edmonston, B., \& Fong, E. (Eds.). (2011). The changing Canadian population. Kingston, ON: McGill-Queen's University Press.

Employment and Social Development Canada. (2014). Homelessness strategy. Retrieved from http://www.esdc. gc.ca.libaccess.lib.mcmaster.ca/eng/communities / homelessness/index.shtml

Fiedler, R., Schuurman, N., \& Hyndman, J. (2006). Hidden homelessness: An indicator-based approach for examining the geographies of recent immigrants at-risk of homelessness in Greater Vancouver. Cities, 23(3), 205-216.

Gaetz, S., Donaldson, J., Richter, T., \& Gulliver, T. (2013). The state of homelessness in Canada 2013. Toronto, ON: Canadian Homelessness Research Network Press. Retrieved from http://www.homelesshub.ca/ (S(dp2ng045tmqvvifvve3eob3v))/Library/The- Stateof-Homelessness-in-Canada-2013-55941.aspx

Gaetz, S. (2006). Safe streets for whom? Homeless youth, social exclusion, and criminal victimization. Canadian Journal of Criminology and Criminal Justice, 46(4), 423-456.

Garibaldi, B., Conde-Martel, A., \& O'Toole, T. P. (2005). Selfreported comorbidities, perceived needs, and sources 
for usual care for older and younger homeless adults. Journal of General Internal Medicine, 20(8), 726-730.

Goering, P., Veldhuizen, S., Watson, A., Adair, C., Kopp, B., Latimer, E., et al. (2014). National at home/Chez Soi final report. Calgary, AB: Mental Health Commission of Canada. Retrieved from http:/ / www.mentalhealthcommission. ca/English

Gonyea, J. G., Mills-Dick, K., \& Bachman, S. S. (2010). The complexities of elder homelessness, a shifting political landscape and emerging community responses. Journal of Gerontological Social Work, 53(7), 575-590.

Gouvernement du Québec. (2014). Ensemble, pour éviter la rue et en sortir: Politique Nationale de lute á l'itinérance. Québec. Retrieved from the Gouvernement du Québec website: http: / / publications.msss.gouv.qc.ca/acrobat/f / documentation/2013/13-846-03F.pdf

Greater Vancouver Shelter Strategy Society. (2013). Sheltering homeless seniors literature review. Retrieved from the Greater Vancouver Shelter Strategy website: http:/ / www. gvss.ca/Other-Docs.html

Greenwood, R. M., Schaefer-McDaniel, N. J., Winkel, G., \& Tsemberis, S. J. (2005). Decreasing psychiatric symptoms by increasing choice in services for adults with histories of homelessness. American Journal of Community Psychology, 36(3-4), 223-238.

Grossman, S. F., \& Lundy, M. (2003). Use of domestic violence services across race and ethnicity by women aged 55 and older: The Illinois experience. Violence Against Women, 9(12), 1442-1452.

Hecht, L., \& Coyle, B. (2001). Elderly homeless: A comparison of older and younger adult emergency shelter seekers in Bakersfield, California. The American Behavioral Scientist, 45(1), 66-79.

Hibbs, J. R., Benner, L., Klugman, L., Spencer, R., Macchia, I., Mellinger, A. K., et al. (1994). Mortality in a cohort of homeless adults in Philadelphia. The New England Journal of Medicine, 331(5), 304-309.

Horn, A. (2008). Medical care for the homeless elderly. Care Management Journals, 9(1), 25-30.

Hulchanski, J. D. (2000). A new Canadian pastime? Counting homeless people. Toronto, ON: University of Toronto. Retrieved from the University of Toronto website: http:/ / www.urbancenter.utoronto.ca/pdfs/researchassociates / Hulch_CountingHomelessPeople.pdf

Hwang, S. W. (2001). Homelessness and health. Canadian Medical Association Journal, 164(2), 229-233.

Hwang, S. W., Lebow, J. M., Bierer, M. F., O'Connell, J. J., Orav, E.J., \& Brennan, T. A. (1998). Risk factors for death in homeless adults in Boston. Archives of Internal Medicine, 158(13), 1454-1460.

Johnsen, S., Cloke, P., \& May, J. (2005). Transitory Spaces of Care: Serving Homeless People on the Street. Health and Place, 11(4), 323-336.
Kellogg, F. R., \& Horn, A. (2012). The elderly homeless: A study comparing older and younger homeless persons, with three case histories. Care Management Journals, 13(4), 238-245.

Khandor, E., \& Mason, K. (2008). Research Bulletin \# 3: Homelessness and crack use. Toronto, ON: The Street Health Report, 2007.

Kim, M. M., Ford, J. D., Howard, D. L., \& Bradford, D. W. (2010). Assessing trauma, substance abuse, and mental health in a sample of homeless men. Health and Social Work, 35(1), 39-48.

Klodawsky, F. (2009). Home spaces and rights to the city: Thinking social justice for chronically homeless women. Urban geography, 30(6), 591-610.

Koegel, P., Melamid, E., \& Burnam, M. A. (1995). Childhood risk factors for homelessness among homeless adults. American Journal of Public Health, 85(12), 1642-1649.

Kosor, A. J., \& Kendal-Wilson, L. (2002). Older homeless women: Reframing the stereotype of the bag lady. Affilia, 17(3), 354-370.

Kuhn, R., \& Culhane, D. P. (1998). Applying cluster analysis to test a typology of homelessness by pattern of shelter utilization: Results from the analysis of administrative data. American Journal of Community Psychology, 26(2), 207-232.

Kushel, M. B., Evans, J. L., Perry, S., Robertson, M. J., \& Moss, A. R. (2003). No door to lock: Victimization among homeless and marginally housed persons. Archives of Internal Medicine, 163(20), 2492-2499.

Laird, G. (2007). Homelessness in a growth economy: Canada's 21st century paradox. Calgary, AB: Sheldon Chumir Foundation for Ethics in Leadership.

Lange, L. (2010). Elderly people of Aboriginal origin in Winnipeg: Their struggle to secure safe and affordable housing (Unpublished master's thesis). Winnipeg, MB: University of Manitoba.

Lee, B. A, \& Schreck, C. J. (2005). Danger on the streets: Marginality and victimization among homeless people. American Behavioral Scientist, 48(8), 1055-1081.

Lee, B. A., Tyler, K. A., \& Wright, J. D. (2010). The new homelessness revisited. Annual Review of Sociology, 36, 501.

Link, B. G., Susser, E., Stueve, A., Phelan, J., Moore, R. E., \& Struening, E. (1994). Lifetime and five-year prevalence of homelessness in the United States. American Journal of Public Health, 84(12), 1907-1912.

Lipmann, B. (2009). Elderly homeless men and women: Aged care's forgotten people. Australian Social Work, $62(2), 272-286$.

Lynch, J. (2001). The age-orientation of social policy regimes in OECD countries. Journal of Social Policy, 30(3), 411-436.

Martins, D. C. (2008). Experiences of homeless people in the health care delivery system: A descriptive phenomenological study. Public Health Nursing, 25(5), 420. 
McDonald, L., Dergal, J., \& Cleghorn, L. (2004). Homeless older adults research project: Executive summary. Toronto, ON: University of Toronto.

McDonald, L., Dergal, J., \& Cleghorn, L. (2007). Living on the margins: Older homeless adults in Toronto. Journal of Gerontological Social Work, 49(1-2), 19-46.

McDonald, L., Donahue, P., Janes, J. \& Cleghorn, L. (2006). In from the streets: The health and well being of formerly homeless older adults. Report for the National Research Program of the National Homelessness Initiative, Human Resources and Skills Development Canada (HRSDC). Toronto, ON: University of Toronto. Retrieved from the Substance Abuse and Mental Health Services Administration website: http:/ / homeless.samhsa.gov/ResourceFiles/NRP_027_ EN_InFromtheStreets_The_Health_and_Well_Being.pdf

McGhie, L., Grenier, A., \& Barken, R. (2013). Literature review on housing options for older homeless people. Hamilton, ON: Gilbrea Centre for Studies on Aging, McMaster University.

Metraux, S., \& Culhane, D. P. (2006). Recent incarceration history among a sheltered homeless population. Crime and Delinquency, 52(3), 504-517.

Morris, A., Judd, B., \& Kavanagh, K. (2005). Marginality amidst plenty: Pathways into homelessness for older Australians. Australian Journal of Social Issues, 40(2), 241-251.

Morrison, D. S. (2009). Homelessness as an independent risk factor for mortality: Results from a retrospective cohort study. International Journal of Epidemiology, 38(3), 877-883.

Mott, S. (2012). Modelling patterns of shelter use at the Old Brewery Mission: Describing program populations, and applying a typology of homelessness. (Unpublished master's thesis). Montreal, QC: McGill University.

Mott, S., Moore, M., \& Rothwell, D. (2012). Addressing homelessness in Canada: Implications for intervention strategies and program design. Montreal, QC: Centre for Research on Children and Families, McGill University.

North, C., Smith, E., \& Spitznagel, E. L. (1994). Violence and the homeless: An epidemiologic study of victimization and aggression. Journal of Traumatic Stress, 7(1), 95-110.

O'Connell, J. J., Roncarati, J. S., Reilly, E. C., Kane, C. A., Morrison, S. K., Swain, S. E., \& Jones, K. L. (2004). Old and sleeping rough: Elderly homeless persons on the streets of Boston, MA. Care Management Journals, 5(2), 101-106.

Patrick, C. (2014). Aboriginal homelessness in Canada: A literature review. Toronto, ON: Canadian Homelessness Research Network Press. Retrieved from http:/ / www.homelesshub. ca/sites/default/files / AboriginalLiteratureReview. pdf

Peressini, T. (2007). Perceived reasons for homelessness in Canada: Testing the heterogeneity hypothesis. Canadian Journal of Urban Research, 16(1), 112-126.

Ploeg, J., Hayward, L., Woodward, C., \& Johnston, R. (2008). A case study of a Canadian homelessness intervention programme for elderly people. Health and Social Care in the Community, 16(6), 593-605.

Power, R., \& Hunter, G. (2001). Developing a strategy for community-based health promotion targeting homeless populations. Health Education Research, 16(5), 593-602.

Proehl, R. A. (2007). Social justice, respect, and meaningmaking: Keys to working with the homeless elderly population. Health and Social Work, 32(4), 301-307.

Quine, S., Kendig, H., Russell, C., \& Touchard, D. (2004). Health promotion for socially disadvantaged groups: The case of homeless older men in Australia. Health Promotion International, 19(2), 157-165.

Rahder, B. (2006). The crisis of women's homelessness in Canada: Summary of the CERA report. Women and Environments International Magazine, 70/71, 38-39.

Rank, M. R., \& Williams, J. H. (2010). A life course approach to understanding poverty among older American adults. Families in Society, 91(4), 337-341.

Rich, A. R., \& Clark, C. (2005). Gender differences in response to homelessness services. Evaluation and Program Planning, 28(1), 69-81.

Rosario, M., Schrimshaw, E.W., \& Hunter, J. (2012). Risk factors for homelessness among lesbian, gay, and bisexual youths: A developmental milestone approach. Children and Youth Services Review, 34(1), 186-193.

Rothwell, D. W., \& Haveman, R. (2013). Definition and measurement of asset poverty in Canada (SSRN Working Paper No. ID 2367057). Rochester, NY: Social Science Research Network. Retrieved from http: / papers.ssrn. com/sol3 / papers.cfm?abstract_id $=2367057$

Rothwell, D. W., \& Mott, S. (2013, June). Profiles and perceptions: Analysis of treatment first transitional housing clients. Poster presented at the International Homelessness Research Conference, Philadelphia, PA.

Schanzer, B., Dominguez, B., Shrout, P. E., \& Caton, C. L. M. (2007). Homelessness, health status, and health care use. American Journal of Public Health, 97(3), 464-469.

Serge, L., \& Gnaedinger, N. (2003). Housing options for elderly or chronically ill shelter users. Ottawa, ON: Canadian Mortgage and Housing Corporation. Retrieved from http:/ / publications.gc.ca/collections/collection_2011/ schl-cmhc/nh18-1/NH18-1-14-2003-eng.pdf

Shinn, M., Gottlieb, J., Wett, J. L., Bahl, A., Cohen, A., \& Baron Ellis, D. (2007). Predictors of homelessness among older adults in New York City: Disability, economic, human and social capital and stressful events. Journal of Health Psychology, 12(5), 696-708.

Shlay, A. B., \& Rossi, P. H. (1992). Social science research and contemporary studies of homelessness. Annual Review of Sociology, 18, 129-160.

Skaburskis, A. (2004). Decomposing Canada's growing housing affordability problem: Do city differences matter? Urban Studies, 41(1), 117-149. 
Social Planning and Research Council of BC. (2005). On our streets and in our shelters: Results from the 2005 Greater Vancouver homeless count. Vancouver, BC: Author. Retrieved from Metro Vancouver website: http:/ / www.metrovancouver.org/services / regionalplanning/homelessness / HomelessnessPublications / HomelessCount2005.pdf

Springer, J., Webber, S., \& Lum, J.M. (2011). Working poor immigrants and housing insecurity. Toronto, ON: CERIS The Ontario Metropolis Centre. Retrieved from http:/ / www.ceris.metropolis.net

Statistics Canada. (2001). Collective dwellings. 2001 Census: Analysis series. Ottawa, ON: Author. Retrieved from http:/ / www12.statcan.gc.ca/english/census01/Products / Analytic/companion/coll/contents.cfm

Statistics Canada (2012). Collective dwellings. 2011 Census reference material:Census dictionary. Ottawa, ON: Author. Retrieved from http:/ / www12.statcan.gc.ca/census-recensement/ 2011/ ref/dict/dwelling-logements002-eng.cfm

Stein, J. A., Leslie, M. B., \& Nyamathi, A. (2002). Relative contributions of parent substance use and childhood maltreatment to chronic homelessness, depression, and substance abuse problems among homeless women: Mediating roles of self-esteem and abuse in adulthood. Child Abuse and Neglect, 26(10), 1011-1027.

Stergiopoulos, V., \& Herrmann, N. (2003). Old and homeless: A review and survey of older adults who use shelters in an urban setting. The Canadian Journal of Psychiatry / La Revue canadienne de psychiatrie, 48(6), 374-380.

Stuart, H., \& Arboleda-Flórez, J. (2000). “Homeless shelter users in the postdeinstitutionalization era": Reply.
The Canadian Journal of Psychiatry / La Revue canadienne de psychiatrie, 45(9), 845.

Toro, P. A. (2007). Toward an international understanding of homelessness. Journal of Social Issues, 63(3), 461-481.

Trypuc, B., \& Robinson, J. (2009). Homelessness in Canada: A funder's primer on understanding the tragedy on Canada's streets. King City, ON: Charity Intelligence Canada.

Tully, C. T., \& Jacobson, S. (1994). The homeless elderly: America's forgotten population. Journal of Gerontological Social Work, 22(3-4), 61-81.

United Nations Organization. (2005). Report on adequate housing (delivered by Miloon Kothari). 61st session of the United Nations Commission on Human Rights. Geneva, Switzerland: United Nations Organization.

Wakabayashi, C., \& Donato, K. M. (2006). Does caregiving increase poverty among women in later life? Evidence from the health and retirement survey. Journal of Health and Social Behavior, 47(3), 258-274.

Waldbrook, N. (2013). Formerly homeless older women's experiences with health, housing, and aging. Journal of Women and Aging, 25(4), 337-357.

Walsh, C., Hewson, J., Dooley, D., \& Pauls, K. (2013, October). Housing insecurity and homelessness: Understanding unmet needs of low income pre-seniors. Paper presented at the 42nd Annual Scientific and Educational Meeting of the Canadian Association on Gerontology, Halifax, NS.

Wenzel, S. L., Leake, B. D., \& Gelberg, L. (2001). Risk factors for major violence among homeless women. Journal of Interpersonal Violence, 16(8), 739-752. 